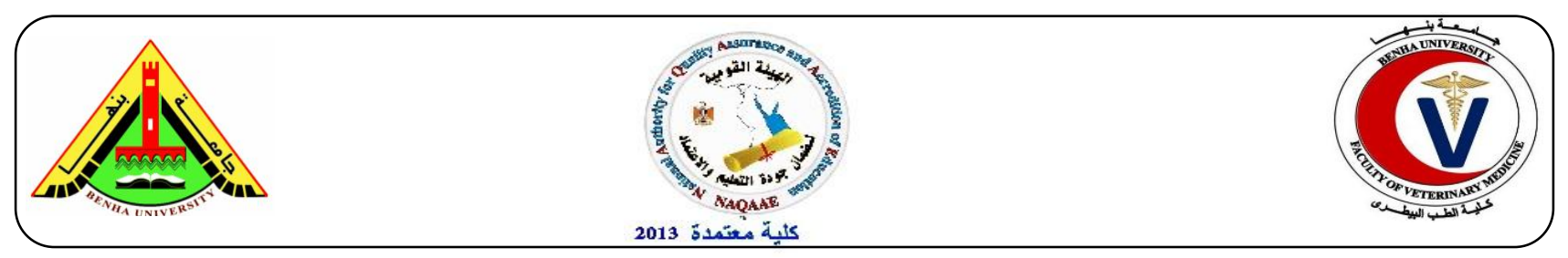

\title{
Effect of Some Essential Oils on the Bacteriological Quality of Some Chicken Meat Products
}

\author{
Ibrahim, H.M. ${ }^{a}$, Hassan, M.A. ${ }^{a}$,Amin, R.A. ${ }^{a}$, Shawqy, N.A.b and Elkoly, R.L. ${ }^{b}$ \\ ${ }^{a}$ Food hygiene Dep., Fac. Vet. Med., Benha Univ. \\ ${ }^{b}$ Animal Health research institute, Shebin el koom branch.
}

\section{A B S T R A C T}

A total of $1500 \mathrm{~g}$ of the fresh minced chicken fillet was purchased from butcher shops in El Menofiya Governorate and directly transferred to the laboratory under complete aseptic condition. Experimental trials were pointed toward the ability to control the outgrowth of Staph aureus in chicken fillet using Nigella sativa oil $(0.1 \%$ and $0.5 \%)$ and rosemary oil $(0.1 \%$ and $0.5 \%)$. The sample was divided into 5 groups. All groups were injected with Staph. aureus reference strain $\left(\right.$ ATCC $\left.^{\circledR} 25923\right)$ and the initial load was $2.6 \times 10^{7} \pm 1.04 \times 10^{7} \mathrm{cfu} / \mathrm{g}$. Control group was inoculated with the tested culture and was stored without treatment with oils. Both oils reduced Staph. aureus levels significantly from zero day till $6^{\text {th }}$ day in the following order: Nigella sativa $0.5 \%>$ Nigella sativa $0.1 \%>$ Rosemary $0.5 \%>$ Rosemary $0.1 \%$. In contrast in the control group, the count increased rapidly till the 4th day of the treatment. Moreover, both oils improved the overall acceptability and prolonged the shelf life of treated samples as it remains without putrefactive changes till $6^{\text {th }}$ day in comparison with control samples which remain without putrefactive changes till $4^{\text {th }}$ day only. Finally, it can be concluded that essential oils possess significant antibacterial activity against the Staph. aureus and increases with increasing their concentration.

Key words: Preservatives, Nigella sativa, Rosemary.

(http://www.bvmj.bu.edu.eg)

(BVMJ-35(1): 42-49, 2018)

\section{INTRODUCTION}

Meat preservation methods became a necessary to transport meat for long distances without spoiling and loss of nutritional value (Nychas et al., 2008).

Traditional chemical or physical preservation processes are very often; but they have various disadvantages such as deterioration of product quality, high degree of reactivity, potential health risks, and consumer product safety concerns, high cost or adverse sensory changes (Lyon et al.,
2007).This explains why manufacturers have turned now to use the natural extracts after the consumer refuse to chemical additives because of their serious health problems (Amin et al., 2015).

Because of the awareness among the consumers, they prefer the meat without any chemical preservatives. Nowadays it has been proven that the best alternative for the chemical preservatives are the essential oils of spices, which can stabilize the meat from 
microbial deterioration (Jagadeesh et al., 2012).

Essential oils and their extracts can be used as natural additives to reduce the use of chemical preservatives and to reduce their risks. Such materials can extend the shelf life of meat and their products and control/inhibit the microbial growth (Stiles and Hastings, 1991). Many of the essential oils have potential benefits in food production since they showed antibacterial, antifungal and antioxidant effects (Politeo et al., 2007).

Different essential oils of different plants showed an effective antimicrobial effects on bacterial count when they are applied in meat products during storage (Angioni et al., 2004).

Nigella sativa (black cumin), belonging to family Ranunculaceae, is famous for its medicinal properties. Seeds of Nigella sativa contain alkaloids, volatile as well as fixed oils and a variety of pharmacologically active substances like thymoquinone, dithymoquinone, carvacrol, thymol, nigellicine- $\mathrm{N}$-oxide, nigellidine and $\alpha$-hedrin. Black cumin is also enriched with the fat content of $35.5 \%$; the seeds of Nigella sativa contain volatile oil (0.5-1.6\%), fixed oil (35.6-41.6\%), protein and amino acids (22.7\%) (Azeem et al., 2014).

Rosemary (Rosmarinus officinalis) is a small ever-green bush, belonging to Labiatae family. It grows principally in the basin of the Mediterranean Sea. Active substances which were contained in Rosmarinus yield have a series of properties, desirable from the point of view of the food industry and medicinal phytology (Djeddi et al., 2007).

\section{MATERIALS AND METHODS}

\subsection{Strain used:}

Staphylococcus aureus reference strain (ATCC $\left.{ }^{\circledR} 25923\right)$, used in this study, was obtained from Bacteriology Unit, Reference Laboratory For Veterinary Quality Control of
Poultry Production, Animal Health Research Institute, Dokki, Giza, Egypt.

2.2. Essential oils:

Rosemary and Nigella sativa oils were purchased from Cap Pharma for Extraction Natural Oils, Plants and Cosmotics. License of Ministry of Health No.33/2006. The concentrations were adjusted to $0.1 \%$ and $0.5 \%$ for each.

\subsection{Minced chicken fillet:}

A grand total of $1500 \mathrm{~g}$ of the fresh minced chicken fillet used in this study was purchased from butcher shops in El Menofiya Governorate. The purchased minced fillet was divided into 5 groups (100gm).

The 5 groups were arranged as follows:

- 1st subgroup: was treated with s. aureus and $0.1 \%$ of Nigella sativa oil.

- 2nd subgroup: was treated with s. aureus and $0.5 \%$ of Nigella sativa oil.

- 3rd subgroup: was treated with s. aureus and $0.1 \%$ of rosemary oil.

- 4th subgroup: was treated with s. aureus and $0.5 \%$ of rosemary oil.

- Control: was inoculated with the tested culture (S.aureus) and was stored without treatment as (Control +ve).

2.4. Experimental application:

- All five groups were inoculated with $S$. aureus reference strain with infective dose $10^{6} \mathrm{cfu} / \mathrm{gm}$, then mixed thoroughly by gently squeezing the bags by hand and leaved for 30 minutes for complete attachment between microorganisms and minced chicken fillet.

- Initial load of $S$. aureus was detected before addition of essential oils. It was 2.6 x $10^{7} \pm 1.0^{4} \times 10^{7} \mathrm{CFU} / \mathrm{g}$.

- The essential oils were added with their certain concentrations to the samples then 
leave them for a further 30 minutes to ensure even mixing.

- Each sample was packed in polyethylene bag, labeled and stored in refrigerator chamber at $4{ }^{\circ} \mathrm{C}$.

- The bacterial $S$. aureus count was estimated at zero day and every $48 \mathrm{hrs}$. to evaluate the effect of the essential oils treatments. Also, organoleptic examination (color, odor, texture and overall acceptability) were conducted

\section{RESULTS}

Results in Table (1) showed that the overall acceptability in case of using Nigella Sativa oil at the concentrations of $0.1 \%$ and $0.5 \%$, the scores were $7,6,5,5,4,4,3$ and 7 , $7,7,6,6,5,4$ at zero day, $1^{\text {st }}, 2^{\text {nd }}, 3^{\text {rd }}, 4^{\text {th }}, 5^{\text {th }}$ day and $6^{\text {th }}$ day of the storage period respectively, while in case of using Rosemary oil at the concentrations of $0.1 \%$ and $0.5 \%$, the scores were $6,5,4,3,3,2,1$ and 7, 5, 5, $4,4,3,2$ at zero day, $1^{\text {st }}, 2^{\text {nd }}, 3^{\text {rd }}, 4^{\text {th }}, 5^{\text {th }}$ day and $6^{\text {th }}$ day of the storage period, respectively, comparing to the scores of overall acceptability in the control samples which were $6,4,4,3,2,1,1$ at zero day, $1^{\text {st }}, 2^{\text {nd }}, 3^{\text {rd }}$, $4^{\text {th }}, 5^{\text {th }}$ day and $6^{\text {th }}$ day of the storage period, respectively.

The results in Table (2) noted that the initial load of Staph. aureus after inoculating the reference strain in the sample is $2.6 \times 10^{7} \pm$ $1.04 \times 10^{7} \mathrm{CFU} / \mathrm{g}$. In case of Nigella sativa oil at the concentrations of $0.1 \%$ and $0.5 \%$, the mean Staph. aureus levels decreased to $1.8 \mathrm{x}$ $10^{7} \pm 3.0 \times 10^{6} \mathrm{cfu} / \mathrm{g}$ and $1.2 \times 10^{7} \pm 1.5 \times 10^{6}$ $\mathrm{cfu} / \mathrm{g}$ at zero day, and to $8.1 \times 10^{6} \pm 2.2 \times 10^{6}$ $\mathrm{cfu} / \mathrm{g}$ and $5.2 \times 10^{6} \pm 1.0 \times 10^{6} \mathrm{cfu} / \mathrm{g}$ in $2^{\text {nd }}$ day, and to $9.2 \times 10^{5} \pm 3.8 \times 10^{5} \mathrm{cfu} / \mathrm{g}$ and after 3 hours and every day $24 \mathrm{hrs}$ intervals during storage until spoilage of samples. (Penny et al., 1993).

- Tests were performed in triplicate.

\subsection{Statistical analysis:}

The data was statistically treated by one way ANOVA using SPSS program for windows (Version 16) (SPSS Inc. Chicago, IL and USA).

$8.6 \times 10^{4} \pm 1.9 \times 10^{4} \mathrm{cfu} / \mathrm{g}$ in $4^{\text {th }}$ day, and to $7.1 \times 10^{5} \pm 3.8 \times 10^{5} \mathrm{cfu} / \mathrm{g}$ and $2.7 \times 10^{3} \pm 1.0$ $\mathrm{X} 10^{3} \mathrm{cfu} / \mathrm{g}$ in $6^{\text {th }}$ day, respectively. In case of Rosemary oil at the concentrations of $0.1 \%$ and $0.5 \%$, the mean Staph. aureus levels decreased to $2.4 \times 10^{7} \pm 7.2 \times 10^{6} \mathrm{cfu} / \mathrm{g}$ and 1.9 $\mathrm{x} 10^{7} \pm 1.5 \times 10^{6} \mathrm{cfu} / \mathrm{g}$ at zero day, and to $2.1 \mathrm{x}$ $10^{7} \pm 5.5 \times 10^{6} \mathrm{cfu} / \mathrm{g}$ and $8.3 \times 10^{6} \pm 0.4 \mathrm{x}$ $10^{6} \mathrm{cfu} / \mathrm{g}$ in $2^{\text {nd }}$ day and to $6.2 \times 10^{6} \pm 2.4 \mathrm{x}$ $10^{6} \mathrm{cfu} / \mathrm{g}$ and $2.7 \times 10^{6} \pm 6.8 \times 10^{5} \mathrm{cfu} / \mathrm{g}$ in $4^{\text {th }}$ day, and to $2.9 \times 10^{6} \pm 2 \times 10^{5} / \mathrm{g}$ and $9.7 \times 10^{5}$ $\pm 1.1 \times 10^{5} \mathrm{cfu} / \mathrm{g}$ in $6^{\text {th }}$ day, respectively. In control, the count was $2.8 \times 10^{7} \pm 6.5 \times 10^{6}$, 1.6 $\times 10^{8} \pm 2.6 \times 10^{7}$ and $8.3 \times 10^{8} \pm 3.4 \times 10^{8}$ at zero, 2nd and 4th day.

The results recorded in Table (3) and Figure (1) revealed that the reduction $\%$ of Staph. aureus with Nigella sativa $0.1 \%$, Nigella sativa $0.5 \%$, Rosemary $0.1 \%$ and Rosemary $0.5 \%$ treatment is $(30.77 \%$, $53.85 \%, 7.69 \%, 26.92 \%$ ) at zero day, and $(68.86 \%, 80.00 \%, 19.23 \%, 68.07 \%)$ at $2^{\text {nd }}$ day, and $(96.46 \%, 99.67 \%, 76.15 \%, 89.61 \%)$ at $4^{\text {th }}$ day, and $(97.27 \%, 99.99 \%, 85.00 \%$, $96.27 \%$ ) at $6^{\text {th }}$ day. 
Table (1): overall acceptability of minced chicken fillet inoculated with Staph. aureus and treated with different concentrations of Nigella Sativa and Rosemary during cold storage at $4^{\circ} \mathrm{C}$.

\begin{tabular}{lcccccccc}
\hline Groups & oil conc. & $\begin{array}{c}\text { Zero } \\
\text { day }\end{array}$ & $\begin{array}{c}1^{\text {st }} \\
\text { day }\end{array}$ & $\begin{array}{c}2^{\text {nd }} \\
\text { day }\end{array}$ & $\begin{array}{c}3^{\text {rd }} \\
\text { day }\end{array}$ & $\begin{array}{c}4^{\text {th }} \\
\text { day }\end{array}$ & $\begin{array}{c}5^{\text {th }} \\
\text { day }\end{array}$ & $\begin{array}{c}6^{\text {th }} \\
\text { day }\end{array}$ \\
\hline \multirow{2}{*}{ Control } & - & 6 & 4 & 4 & 3 & 2 & 1 & 1 \\
Nigella Sativa & $0.1 \%$ & 7 & 6 & 5 & 5 & 4 & 4 & 3 \\
& $0.5 \%$ & 7 & 7 & 7 & 6 & 6 & 5 & 4 \\
Rosemary & $0.1 \%$ & 6 & 5 & 4 & 3 & 3 & 2 & 1 \\
& $0.5 \%$ & 7 & 5 & 5 & 4 & 4 & 3 & 2 \\
\hline
\end{tabular}
Score System for Sensory Evaluation:
9: Excellent
6: Good
3: Poor
8: Very very good
5: Medium 2: Very poor
7: Very good
4: Fair 1: Very very poor

Table (2): Antimicrobial effect of different concentrations of Nigella Sativa and Rosemary essential oils against Staph. aureus count artificially inoculated in minced chicken fillet during cold storage at $4^{\circ} \mathrm{C}$.

\begin{tabular}{lccccc}
\hline Durations & Control & $\begin{array}{c}\text { Nigella } \\
\text { sativa oil } \\
0.1 \%\end{array}$ & $\begin{array}{c}\text { Nigella } \\
\text { sativa oil } \\
0.5 \%\end{array}$ & $\begin{array}{c}\text { Rosemary } \\
\text { oil } 0.1 \%\end{array}$ & $\begin{array}{c}\text { Rosemary } \\
\text { oil } 0.5 \%\end{array}$ \\
\hline Zero day $^{\text {NS }}$ & $2.8 \times 10^{7 \mathrm{a}}$ & $1.8 \times 10^{7 \mathrm{a}}$ & $1.2 \times 10^{7 \mathrm{a}}$ & $2.4 \times 10^{7 \mathrm{a}}$ & $1.9 \times 10^{7 \mathrm{a}}$ \\
& $\pm 6.5 \times 10^{6}$ & $\pm 3.0 \times 10^{6}$ & $\pm 1.5 \times 10^{6}$ & $\pm 7.2 \times 10^{6}$ & $\pm 1.5 \times 10^{6}$ \\
$2^{\text {nd }}$ day $^{++}$ & $1.6 \times 10^{8 \mathrm{a}}$ & $8.1 \times 10^{6 \mathrm{~b}}$ & $5.2 \times 10^{6 \mathrm{~b}}$ & $2.1 \times 10^{7 \mathrm{~b}}$ & $8.3 \times 10^{6 \mathrm{~b}}$ \\
& $\pm 2.6 \times 10^{7}$ & $\pm 2.2 \times 10^{6}$ & $\pm 1.0 \times 10^{6}$ & $\pm 5.5 \times 10^{6}$ & $\pm 0.4 \times 10^{6}$ \\
$4^{\text {th }}$ day $^{+}$ & $8.3 \times 10^{8 \mathrm{a}}$ & $9.2 \times 10^{5 \mathrm{~b}}$ & $8.6 \times 10^{4 \mathrm{~b}}$ & $6.2 \times 10^{6 \mathrm{~b}}$ & $2.7 \times 10^{6 \mathrm{~b}}$ \\
& $\pm 3.4 \times 10^{8}$ & $\pm 3.8 \times 10^{5}$ & $\pm 1.9 \times 10^{4}$ & $\pm 2.4 \times 10^{6}$ & $\pm 6.8 \times 10^{5}$ \\
$6^{\text {th }}$ day $^{++}$ & - & $7.1 \times 10^{5 \mathrm{a}}$ & $2.7 \times 10^{3 \mathrm{a}}$ & $3.9 \times 10^{6 \mathrm{~b}}$ & $9.7 \times 10^{5 \mathrm{a}}$ \\
& & $\pm 3.8 \times 10^{5}$ & $\pm 1.0 \times 10^{3}$ & $\pm 2.0 \times 10^{5}$ & $\pm 1.1 \times 10^{5}$ \\
\hline
\end{tabular}

Initial load of Staph. aureus $=2.6 \times 10^{7} \pm 1.04 \times 10^{7} \mathrm{CFU} / \mathrm{g}$

The values represent Mean counts \pm S.E. $(C F U / g)$ of three experiments.

Means within the same row not bearing the same superscripts are significantly different.

NS $=$ Non significant differences.

$+=$ Significant differences $(\mathrm{P}<0.05)$

$++=$ High significant differences $(\mathrm{P}<0.01)$ 
Table (3): Reduction \% of Staph. aureus count artificially inoculated into minced chicken fillet samples treated with different concentrations of Nigella Sativa and Rosemary essential oils.

\begin{tabular}{ccccc}
\hline Durations & $\begin{array}{c}\text { Nigella } \\
\text { sativa } \text { oil } \\
(0.1 \%)\end{array}$ & $\begin{array}{c}\text { Nigella } \\
\text { sativa } \text { oil } \\
(0.5 \%)\end{array}$ & $\begin{array}{c}\text { Rosemary oil } \\
(0.1 \%)\end{array}$ & $\begin{array}{c}\text { Rosemary oil } \\
(0.5 \%)\end{array}$ \\
\hline Zero day & 30.77 & 53.85 & 7.69 & 26.92 \\
$2^{\text {nd }}$ day & 68.86 & 80.00 & 19.23 & 68.07 \\
$4^{\text {th }}$ day & 96.46 & 99.67 & 76.15 & 89.62 \\
$6^{\text {th }}$ day & 97.27 & 99.99 & 85.00 & 96.27 \\
\hline
\end{tabular}

$\square^{\text {zero day }} \square^{\text {2nd day }} \square^{\text {4th day }} \square^{\text {6th day }}$

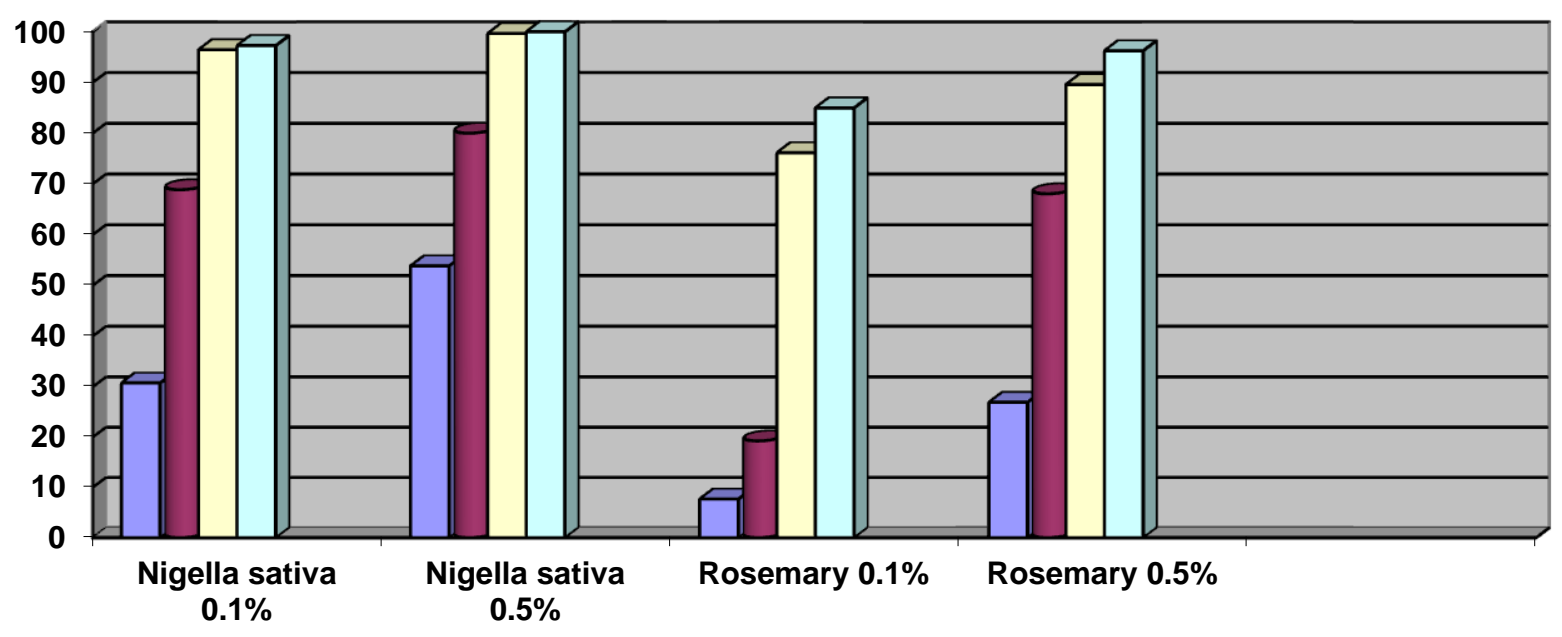

Figure (1): Reduction \% of Staph. aureus count artificially inoculated into minced chicken fillet samples treated with different concentrations of Nigella Sativa and Rosemary essential oils.

\section{DISCUSSION}

There is an increase in using plant-origin food-preservative essential oils since the 1990s, with more utilization of spices and their essential oils as natural biopreservatives, to increase shelf life and overall quality of food products (Simitzis et al., 2008).

Sensory evaluation is an easy, quick and efficient method for getting idea about the quality of the product and its overall acceptance; sensory methods were used to assess the degree of freshness based on organoleptic characteristics such as color, odor, texture and overall acceptability of the product (Haq et al., 2013).

From the obtained results in Table (1) there was a decline of sensory attributes begin after the first day of storage with marked reduction of overall acceptability values in the control samples at the $4^{\text {th }}$ day of storage. 
Generally, it is obvious that the sensory attributes and shelf life of different treated minced chicken fillet samples during cold storage $\left(4^{\circ} \mathrm{C}\right)$ were improved by using different concentrations of Nigella sativa and Rosemary oils, compared to the control samples during the storage period. Samples treated with Nigella Sativa oil revealed the higher improvement of sensory attributes than samples treated with Rosemary oil.

These results nearly agreed with Amin (2013) who illustrated that different essential oils improve the sensory attributes of treated meat samples. Also, she concluded that Rosemary oil give lowest effect on sensory attributes of treated samples.

Both type of essential oils prolonged the shelf life of the treated samples (as samples remain without putrefactive changes till $6^{\text {th }}$ day while in control it remain without putrefactive changes till $4^{\text {th }}$ day).

Regarding the results recorded in Table (2), the mean Staph. aureus levels in the examined samples in the four groups treated by the essential oils (each of Nigella sativa and Rosemary $0.1 \%$ and $0.5 \%$ ) were significantly reduced from zero day after treatment till $6^{\text {th }}$ day. The mean bacterial count at $6^{\text {th }}$ day recorded the lowest level among all the examined days. In the control group, the bacterial count increased significantly and rapidly from the beginning of the experiment till the 4th day from the treatment. The organoleptic examinations exhibited putrefactive changes in the control group samples at the $5^{\text {th }}$ day; subsequently, these samples were unfit for the microbiological examinations.

This result agreed with those reported by Amina (2016) who estimated the Staph. aureus count in the broiler fillet of the control group increased rapidly from the beginning of the experiment till the $4^{\text {th }}$ day without putrefactive changes and putrefied at $6^{\text {th }}$ day.
While this result disagreed with those obtained by Abd El-Dayem and Marzouk (2010), who estimated the Staph. aureus count in the broiler fillet of the control group till the 10th day without putrefactive changes, this variation may be explained by the lower initial bacterial count in their study comparing with those in the current investigation.

The lowest Staph. aureus levels in the examined samples in the four groups was achieved by Nigella sativa $0.5 \%$ which gave the highest protection, followed by Nigella sativa $0.1 \%$, followed by Rosemary $0.5 \%$ and finally Rosemary $0.1 \%$ ) which gave the lowest effect on Staph. aureus. The results partially agreed with those reported by Abd El-Dayem and Marzouk (2010), who detected slight decrease of Staph. aureus count in chicken fillet treated with $0.5 \%$ Nigella sativa oil at the $2^{\text {nd }}, 4^{\text {th }}$ and $7^{\text {th }}$ days after treatment comparing with those in the control group. Moreover, Bessedik and Allem (2013) concluded that $0.4 \%$ of Nigella sativa oil had an inhibitory effect against Staph. aureus.

The antibacterial effect of Nigella sativa oil may be due to its content of alkaloids, volatile as well as fixed oils and a variety of pharmacologically active substances like thymoquinone, dithymoquinone, carvacrol, thymol, nigellicine-N-oxide, nigellidine and $\alpha$-hedrin. Black cumin is also enriched with the fat content of $35.5 \%$; the seeds of Nigella sativa contain volatile oil (0.5-1.6\%), fixed oil (35.6-41.6\%), protein and amino acids (22.7\%) (Azeem et al.2014).

The antibacterial effect of Rosemary oil may be due to $\alpha$-pinene which is reported as the major component of Rosemary essential oil, followed by 1,8 - cineole, camphene, $\beta$ myrcene, camphor and borneole. It was determined that Rosemary essential oil exhibits antimicrobial activity by passing through the cell wall and cytoplasm membranes and disrupting their structure as a 
typical lipophilic substance (Stojanović-Radić et al., 2010). Another potent compound is ßcaryophyllene, which may affect accumulation of some substances by increasing permeability of the plasma membrane. In that way, it affects and increases cytotoxic effect of compounds with which it interacts (Legaule, and Pichette, 2007).

The results recorded in Table (3) and Figure (1) revealed that Nigella sativa oil $0.5 \%$ treatment gave the highest reduction \% of Staph. aureus.

Natural preservatives and /or essential oils in certain concentrations have a great role in inhibiting and reduction microbial growth of some microorganisms that have public health hazards.

\section{CONCLUSION}

From this study, it could be concluded that the studied essential oils possess significant antibacterial activity against Staph. aureus, in the following order: Nigella sativa $0.5 \%>$ Nigella sativa $0.1 \%>$ Rosemary $0.5 \%>$ Rosemary $0.1 \%$. Their antibacterial activity increases, when increasing their concentration. Therefore, these essential oils may be selected for use as potential food biopreservatives and anti- Staph. aureus agents in minced chicken meat and other foods, depending upon the desired flavor of the products.

\section{REFERENCES}

Abd-El-Daym, R. and Marzouk, N.M. (2010): Effect of Nigella sativa oil on the microbial quality of chilled chicken fillets. Alex. J. Vet. Sci., 29(1): 51-59.

Amin, Reham, A. (2013): Screening of antibacterial activity of Cinnamon, Clove and Rosemary essential oils against common food borne pathogens in minced beef. J. Benha Vet. Med., 25 (2):151-164.
Amin, Reham A.; Nesrin, Z.E. and Naglaa, A.E. (2015): Effect of thyme oil and clove oil on Staphylococcus aureus in chicken minced meat. J. Agriculture and Food Safety Sciences, 2:45-55.

Amina, H.H. (2016): Control of microbial contamination of chicken meat using some natural additives and surfactants. M.V.Sc. Thesis (Meat Hygiene), Fac. Vet. Med., Zagazig Univ,Egypt.

Angioni, A.; Barra, E.; Cereti, D.; Barile, J.; Coisson, D. and Arlorio, M. (2004): Chemical composition, plant genetic differences, antimicrobial and antifungal activity investigation of the essential oil (Rosmarinusofficinalis L.). J. Agric. Food Chem., 52(11): 35303535 .

Azeem, T.; Zaib-Ur-Rehman; Umar, S.; Asif, M.; Arif, M. and Rahman, A. (2014): Effect of Nigella Sativa on poultry health and production: a review. Sci. Lett., 2 (2):76-82.

Bessedik, A. and Allem, R. (2013): Molecular composition and antibacterial effect of essential oil of Nigella sativa. Afr. J. Biotechnol., 12 (20): 3006- 3012.

Djeddi, S.; Bouchenah, N.; Settar, I. and Skaltsa, H.D. (2007): Composition and antimicrobial activity of the essential oil of Rosmarinus officinalis L. from Algeria. Chem. Natural Comp., 43 (4): 487- 490 .

Haq, M.; Dutta, P.L.; Sultana, N. and Rahman, A. (2013): Production and quality assessment of fish burger from the grass carp, Ctenopharyngodon idella (Cuvier and Valenciennes, 1844), J. Fisheries, 1(1): 42-47.

Jagadeesh, A.; Rupasundari, A.; Sankar, B. and Sravanthi, M. (2012): Studies on the antimicrobial effectiveness of essential oils of garlic, clove and 
cinnamon on staphylococcus aureus in chicken meat patties. Tamilnadu J. Veterinary \& Animal Sciences 8 (1):4549.

Legaule, J. and Pichette, A. (2007): Potentiating effect of $B$-caryophyllene on anticancer activity of $\alpha$ - humulene, isocaryophyllene and paclitaxel. $\mathrm{J}$. Pharmacy and Pharmacol., 59 (12):1643-1647.

Lyon, S.A.; Fletcher, D.L. and Berrang, M.E. (2007): Germicidal ultraviolet light to lower numbers of Listeria monocytogenes on broiler breast fillets. Poult. Sci., 86(5): 964-967.

Nychas, G.; Skandamis, C.; Tassou, A. and Koutsoumanis, K. (2008): Meat spoilage during distribution. J. Meat Sci., 78: 77-89.

Politeo, O.; Jukic, M. and Milos, M. (2007): Chemical composition and antioxidant capacity of free volatile aglycones from basil (Ocimumbasilicum.) compared with its essential oil. J. Food Chem., 101: 379-385.

Penny, N.; Hagyard, C.A. and Bell, R.G. (1993): Extension of shelf life of chilled sliced roast beef in carbon dioxide packing. Int. J. Sci. Tech., 28(2): 181191.

Simitzis, P.E.; Deligeorgis, S.G.; Bizelis, J.A.; Dardamani, A.; Theodosiou, I. and Fegeros, K. (2008): Effect of dietary oregano oil supplementation on lamb meat characteristics. Meat Science, 79 (2): 217-223.

Steel, R.G.D. and Torrie, J.H. (1980): Principles and Procedures of Statistics, 2nd Edition, New York: McGraw-Hill.

Stiles, M.E. and Hastings, J.W. (1991): Bacteriocins production by lactic acid bacteria: potential for use in meat preservation. Trends Food Sci. Technol., 2: 247-251.

Stojanović-Radić, $\quad$ Z.; Nešić1, M.; LjiljanaČomić, L. and Radulović, N. (2010): Antimicrobial activity and cytotoxicity of commercial rosemary essential oil (Rosmarinus officinalis L.). Biologica. Nyssana., 1 (1-2): 83-88. 